\title{
Guarantee of Religious Practices as a Part of the Cultural Security of Polish-Speaking Catholics Living in Germany
}

\author{
Arkadiusz Urbanek / e-mail: urbane.arkadiusz@vp.pl \\ University of Wroclaw, Institute of Pedagogy, Poland. \\ Marek Pelczar / e-mail: pelczarmarek@op.pl \\ University of Wroclaw, Institute of Pedagogy, Poland
}

Urbanek, A. - Pelczar, M. (2018). Guarantee of Religious Practices as a Part of the Cultural Security of Polish-Speaking Catholics Living in Germany. Czech-Polish Historical and Pedagogical Journal, 10/2, 65-76.

https://doi.org/10.5817/cphpj-2018-015

The paper deals with three problematic threads, i.e. defining cultural security, the issue of legal guarantees due to a national minority in a foreign country, and the results of a research conducted among the Polish community in Germany. Field research was conducted using a technique of questionnaire interviews in the community associated with two Polish diaspora organizations: Polish Catholic Mission in Hamburg and Gazeta Polska ("Polish Newspaper") in Hamburg. The aim of the discussion is to answer the following question: do Polish-speaking Catholics, representing the national minority in Germany, perceive threats to their own religious practices? The results of the research have highlighted the perspective of representatives with extreme and moderate views on the right to manifest religious identity in Germany.

Key words: religion; church; minority; Catholics

Culture and religion are an essential and universal attribute of human nature, therefore, when considering these social, political, and legal situations of the Polish minority in Germany, these two aspects take on a special significance. Catholic religion is closely related to Polish identity and Polish culture, because over the centuries, the Roman Catholic Church has been associated with the nation and there has occurred "a connection of Polish national and Catholic identity". Therefore, the activity of religious unions and church institutions is to cultivate not only the tradition, but also the human identity.

Nowadays, the issue of religiosity is becoming very important in the context of globalization processes. It draws attention to the issue of objective guarantees and subjective sense of cultural security that do not succumb to amalgamation

1 Casanova, J. (2005). Religie publiczne w nowoczesnym świecie. Kraków, 161. 
processes. Globalization is associated with intensification of intercultural contacts, the tendency to unify (homogenize) cultures, multiculturalism policy, and with commercialization of cultures. There is a space created to make cultures similar to one another. ${ }^{2}$ However, among national and ethnic minorities and diasporas, these processes of amalgamation of cultures collide with opposing pursuit. Minority communities can even intensify activities aimed at preserving individuality and identity. In that case, the analysis of the role of religiosity and church institutions, as well as striving to manifest cultural identity may be key aspects of shaping the sense of cultural security. The result is striving to exaggerate and contrast the cultural identity, so there is an aspiration towards disintegration. ${ }^{3}$ The manifestations of attacks on the values, principles, and religious symbols evoke spreading waves of indignation or aggressiveness. An example is the publication in 2005 of drawings / cartoons depicting the Prophet Muhammad by a Danish newspaper, "Jyllands-Posten". Initially, the confusion was local, however, reprints of drawings in other European newspapers caused not only criticism on a wider scale, but also riots in Muslim countries. Anthony Giddens emphasizes that the contemporary issue of freedom of speech, which seemed to be more or less globally resolved, is again being raised in a dramatic way, as he defines specifies it. According to him, this is related to the return of sacrum, and that the threat or the actual use of force arises where beliefs or symbols are considered to be profaned. ${ }^{4}$ Thus, social groups are ready to fight for their own sense of cultural security.

The analysed cultural security is interpreted in the context of various aspects, generally encouraging the development and consolidation of legal, safe forms of promoting a culture and religion. This approach is especially valuable for describing the situation of Poles in Germany. Although it is not an officially recognized minority according to EU law, it reserves the right to protect the cultural and religious identity. According to Grażyna Michałowska, [...] cultural security in the national dimension means the conditions in which society can consolidate and cultivate the values that determine its identity, and, at the same time, freely draw on the experiences and achievements of other nations. ${ }^{5}$ It is, of course, about the values that make up the cultural and national identity of society. ${ }^{6}$ Cultural security interpreted by Tadeusz Jemioło indicates "its ability to multiply its cultural achievements and defend against the undesirable influence of other

2 Jacko, J. F. (2008). Globalizacja a różnice kulturowe. Przyczynek do metodologii badań międzykulturowych. In B. Krauz-Mozer, P. Borowiec, Globalizacja - nieznośne podobieństwo? Świat i jego instytucje w procesie uniformizacji. Kraków, 14-15.

3 Ziętek, A. W. (2013). Bezpieczeństwo kulturowe w Europie. Lublin, 104.

4 Giddens, A. (2009). Europa w epoce globalnej. Warszawa, 161.

5 Michałowska, G. (1997). Bezpieczeństwo kulturowe w warunkach globalizacji procesów społecznych. In Zięba, R. - Bobrow, D. B. - Haliżak, E. (1997). Bezpieczeństwo narodowe i międzynarodowe u schyłku XX wieku. Warszawa, 132.

6 See: Żarkowski, P. - Topolewski, S. (2014). Współczesne bezpieczeństwo kulturowe. Siedlce, 33. 
cultures."7 According to Jan Czaja, "cultural security, first and foremost, is the ability of the state to protect its cultural identity, cultural goods and national heritage, including the symbols that make up the national identification ensemble, or national identity." ${ }^{\prime \prime}$ In these approaches, there is a different direction for implementing this security; on the one hand, it activates social groups, and in this case, they may be the Polish national organizations in Germany. On the other hand, it indicates the role of the state and formal institutions guaranteeing the space to maintain this security. This is both the role of the host country, such as Germany, and the state from which the minority ${ }^{9}$ grew, for example, Poland. The issue of interstate relations at the point of contact of aspirations for preserving cultural or religious separateness has its clear determinants in international law. This is necessary because there is always a doubt about the limits of interference of a foreign country in the internal policy of another state. For this reason, considering conditions for the cultural security of Poles in Germany, the analysis of legal guarantees is important.

The multitude of definitions and concepts of cultural security shows various approaches to this issue. It encompasses: freedom of thought, conscience, language, lifestyle, ethnicity, gender, religious practices, customs, cultivated traditions, etc. It also refers to the space of cultural and public activity, consociating, membership in associations and unions, or even competition in culture. In this context, there are highlighted close links between cultural security and human and ethnic rights and freedoms, efficiency of national institutions, level of education of the society, condition of native science, media efficiency and objectivity, socially desirable state of public morality, attention to language purity or generally understood cultural heritage. ${ }^{10}$ An unnegotiable element of this security is also the possibility to develop the culture. ${ }^{11}$ In the United States,

7 Jemioło, T. (2001). Bezpieczeństwo kulturowe w warunkach globalizacji i procesów społecznych. Kultura narodowa w kształtowaniu świadomości obronnej społeczeństwa i bezpieczeństwa państwa. Zeszyt problemowy TWO, 20.

8 Czaja, J. (2008). Kulturowe czynniki bezpieczeństwa. Kraków, 106.

9 A minority not in the formal and legal sense, but as a group living among others, representing a different tradition and religious ritual, derived from the Polish Catholic church.

10 See: Czaja, J. Op. cit.; Huntington, S. (2006). Zderzenie cywilizacji i nowy kształt ładu światowego. Warszawa; Kubiak, M.: O bezpieczeństwie w perspektywie kulturowe. In J. Zajdzik, T. Iwanek (Eds.), Socjologiczne aspekty wojsk i obronności. Warszawa 2004; Michałowska, G. (1994). Kulturowe czynniki bezpieczeństwa. In J. Kukułka (Ed.), Bezpieczeństwo międzynarodowe $w$ Europie Środkowej po zimnej wojnie. Warszawa; Sałaciński, K. (2001). Bezpieczeństwo dóbr kultury. Nowe idee i technologie. Warszawa; Włodkowska, A. (2009). Bezpieczeństwo kulturowe. In K. A. Wojtaszczyk, A. MaterskaSosnowska (Eds.), Bezpieczeństwo państwa. Warszawa.

11 Żarkowski, P. - Topolewski, S. (2014). Współczesne bezpieczeństwo kulturowe. Siedlce, 34. 
cultural security is defined as: "the ability of society to protect its specific nature in changing conditions and against real or apparent threats. Security means maintaining the durability of traditional language patterns, culture, associations, identities, national customs and religious practices, taking into account those changes that are consistent with these principles and can be accepted." This definition emphasizes what is extremely important for the development of culture, namely its evolution, development through internalisation (adding) of noncontradictory (to cultural identity) elements, incorporation into its own system of values. However, this sphere is so important from the point of view of the state's interest that a special institution dealing with cultural security in the U.S.A. has been established. 12

In the context of the considered issue of the guarantee to respect the religious rights of Polish-speaking Catholics in Germany, Waldemar Kitler emphasized an important aspect of cultural security. In his opinion, the implementation of cultural security objectives requires the state to take all actions aimed at the protection of cultural property, as well as to use the cultural heritage of the nation in favour of shaping desirable conditions in the international environment and reinforcing national strength in accordance with the objectives of the national strength.13 Shaping attitudes related to the national and cultural affiliation of the Polish minority in Germany also appears to be an important task. According to W. Kitler, cultivating the cultural heritage of a nation is an element of the foreign cultural policy of the state in order to reinforce its national strength. In this context, the aspect of defining cultural security in the pragmatic dimension is particularly interesting. It means the ability of a state to protect its cultural identity, cultural goods and national heritage, but with promoting synergies between cultures and openness to diversity and not to nationalism. Cultural security interpreted in this way includes the following factors:

1) protection of the symbolic (spiritual) culture values, essential for the national identity (language, religion, customs, historical traditions, literature, philosophy, ideology, etc.)

2) protection of material cultural goods and cultural heritage (monuments)

3) sense of cultural security concerns the nation (national identity), individuals (freedom of contacts), and ethnic groups (cultural differences related to ethnicity, national minorities).

The concept of openness of culture consists primarily in maintaining a balance between its internal development, based on native values, and protection against undesirable influences and simultaneous internalization of non-contradictory elements. This balance is of key importance for cultural security in the field of

12 Czaja, J. (2008). Kulturowe czynniki bezpieczeństwa. Kraków. Krakowska Szkoła Wyższa im. A. F. Modrzewskiego, 35.

13 Kitler, W. (2002). Obrona narodowa III RP. Zeszyty naukowe AON, 339. 
spiritual culture, which is why cultural security is so closely related to the internal and foreign policy of the state, as well as the policy of national security and the national security strategy. ${ }^{14}$

\section{Guarantees of cultural security of a national minority in the light of international law}

In the context of the discussed guarantees of religious practices forming a part of cultural security, it is justified to emphasize the relationship between cultural security and human rights and freedoms, focusing on the protection of freedom of religion in the European Union.

In the integration process of the European Union, religion occupies a very important place and is the foundation in creating the identity of national communities. The religiosity of citizens of a state affects its shape and the presence of values in public life. In the modern world, the state as an institution regulates its position towards churches and religious associations in various models of separation of these two institutions. Models of church and state separation break with the privileged position of religion in the structure of society and the state. ${ }^{15}$ The European Union has not enunciated a uniform model of relations with churches and religious associations, because the sphere of religiosity is not the subject of interest of the Union that maintains religious neutrality. Nevertheless, for many years, when the EU structures were being formed, there were also mechanisms determining the way of referring to churches and religious associations. Over the years, these mechanisms have been reflected in the treaty law and sanctioned as relations between ecclesiastical and EU institutions. ${ }^{16}$

The Community has no general competence, and its powers derive from the transfer of competences by the Member States in certain areas. In 1992, the principle of subsidiarity acquired legal validity in the Maastricht Treaty, ${ }^{17}$ because the community operates within the powers conferred by this treaty and the objectives set out in it. To the extent that is not subject to its exclusive competence, the community undertakes actions, in accordance with the principle of subsidiarity, only if and to the extent to which the objectives of the proposed activities cannot be sufficiently achieved by the Member States, but due to the scale or effects of the proposed actions, they can be better implemented by the

14 Czaja, J. Op. cit., 36-37.

15 Piwowarski, W. (2000). Demokratyczne i społeczne uwarunkowania światopoglądu. In W. Piwowarski (Ed.), Socjologia religii. Lublin, 386.

16 Szawczyk, R. (2011). Kościoły i związki wyznaniowe a prawo traktatowe Unii Europejskiej. Studia Ełckie 13, 353.

17 Maastricht Treaty - signed on 7th February 1992 (entered into force on 1st November 1993). Journal of Laws of 2004, No. 90, item 864/30. 
Community. "No Community action shall go beyond what is necessary to achieve the objectives set out in this Treaty". ${ }^{18}$ According to the above-mentioned provision, it can be concluded that the EU Member States have not delegated competence in religious matters and issues of religious law to the Union institutions. The legal space relating to churches and religious associations falls within the competence of particular Member States. ${ }^{19}$ In the matter of religious law, the Member States are autonomous in relation to the EU institutions, with the exception of linking this law with the law prohibiting discrimination on the grounds of religion.

Article 6 paragraph 1 of the Treaty on European Union stipulates that the European Union is founded on the principles of liberty, democracy, recognition of human rights and fundamental freedoms, as well as the rule of law, understood as the common principles of the Member States. However, paragraph 2 of this Article says that the Union recognizes the fundamental rights, which are guaranteed by the European Convention for the Protection of Human Rights and Fundamental Freedoms, signed in Rome on $4^{\text {th }}$ November 1950, and which result from the common constitutional traditions of the Member States that constitute the basic principles of the EU law. ${ }^{20}$

According to the above, the EU respects Article 9 of the Convention, which involves freedom of religion. Freedom of thought, conscience, and religion is one of the basic values of a democratic society. This freedom cannot be subject to any restrictions. However, the state has the possibility of interference in certain cases. In a democratic and pluralistically diverse society, certain restrictions are necessary to reconcile the interests of different religions and ensure respect for the beliefs of each person. ${ }^{21}$ In paragraph 3 of Article 6, we read that the Union is obliged to respect the national identity of the Member States, and state-church relations are a part of it. The state is therefore there to protect the diversity of church-state relation models as a part of national identity.

It is also legitimate to refer to the Charter of Fundamental Rights, where Article 10 indicates as follows: Freedom of thought, conscience, and religion. Everyone has the right to freedom of thought, conscience, and religion. This right includes the freedom to change religion or belief, alone or together with others, in public or in private, by participating in services, teaching, customs, and rites. ${ }^{22}$

18 Article $3 \mathrm{~b}$ of the TEU (Maastricht Treaty).

19 Pietrzak, M. (2005). Prawo wyznaniowe. Warszawa, 288.

20 European Convention for the Protection of Human Rights and Fundamental Freedoms; Journal of Laws of 1993, No. 61, item 246 and Protocol No. 11; Journal of Laws of 2009, No. 147, item 962.

21 Nowicki, M. A. (2009). Wokół konwencji Europejskiej. Komentarz do Europejskiej Konwencji Praw Człowieka. Warszawa, 398-399.

22 Charter of Fundamental Rights, 2007/C 303/01, Title II, Freedoms, Article 10. 
In Article 14 paragraph 3, the Charter refers to the right of parents to bring up their children in accordance with their own beliefs: "freedom to create educational institutions while respecting democratic principles, as well as the right of parents to ensure upbringing and teaching of children, in accordance with their own religious, philosophical, and pedagogical beliefs, are guaranteed in accordance with national regulations governing the exercise of such freedom." 23

The next act regulating the discussed issue is the Constitutional Treaty, where in Article I-52, paragraphs 1-3, we can read:

1. "The Union shall respect the status granted under national law to churches and religious associations or communities in the Member States and shall not violate that status.

2. The Union respects equally the status of philosophical and non-religious organizations granted to them under national law.

3. Recognizing the identity and special contribution of these churches and organizations, the Union maintains an open, transparent, and regular dialogue with them." 24

\section{Situation of Polish-Speaking Catholics in Germany}

Taking into account the situation of Polish-speaking Catholics living in Germany, attention should be drawn to the guarantees of the Treaty between the Republic of Poland and the Federal Republic of Germany on good neighbourliness and friendly cooperation. The document was signed in Bonn on the $17^{\text {th }}$ June 1991, where in Article 20 paragraph 3 it emphasizes, inter alia, the right to:

- "free use of mother tongue in private and public life, access to information in this language, its dissemination and exchange

- establishing and maintaining educational, cultural and religious institutions, organizations or associations that can apply for voluntary financial and other contributions, as well as for public aid, in accordance with national law, and that have equal access to the media of their region

- professing and practising the religion, including the acquisition, possession, and use of religious materials, as well as conducting religious education in mother tongue."

The issue of religion in Germany, apart from legal regulations, is also reflected in the statements of politicians. Angela Merkel, speaking on the occasion of the $500^{\text {th }}$ anniversary of the Reformation in Wittenberg, pointed to the importance of freedom of religion, carried out within constitutional rights. "Tolerance is the soul of Europe, the foundation of open societies, and its manifestation is religious

\footnotetext{
23 Ibidem, Article 14.

24 Treaty establishing a Constitution for Europe, Luxembourg 2005.
} 
freedom. Therefore, the state's task is to protect freedom of religion," Merkel said, recalling that there are believers of many religions living in Germany. "Freedom of religion must not only be protected from religious fanaticism, but it also obliges to protect religion from disdain," she stressed. "Tolerance ends where our constitutional values of freedom and human rights are violated and trampled on," Angela Merkel explained. ${ }^{25}$

It is also worth referring to the functioning of the Catholic church and Polish-speaking Catholics in Germany in the European context. The published data of the Institute of Catholic Church Statistics (Instytut Statystyki Kościoła Katolickiego, ISKK) on the religiousness of Polish Catholics invite a question about the place of Poland on the map of European religiosity. In the countries of the European Union, the declaration of belonging to the Catholic Church is the most common in Malta, Romania, and Cyprus, and the least in Estonia, Sweden, and the Czech Republic. According to the Eurobarometer data from 2010, the connection to the Catholic Church in Poland is declared by $79 \%$ of inhabitants, putting the country on the fourth place in terms of the number of Catholics (ex aequo with Greece). In the European Union alone, the declaration of Christianity, according to Eurobarometer in 2012, was 72\%, combining Catholics (48\%), Protestants (12\%), Eastern Christians (8\%), and other fractions (4\%). However, having reliable data is extremely difficult, because, as Witold Zdaniewicz points out, most countries do not carry out such research at all. $^{26}$

\section{Practising Religion and the Issue of Threats Perceived in Polish-Speaking Catholics in Germany}

Currently, Polish Catholics are especially often active in German parishes in border regions. In some border regions, $50 \%$ of the faithful are Poles, and this trend is noticed by the German bishops. It does not apply only to local rural communities, because also in large metropolises, such as Berlin, in January 2015, there were registered over 43 thousand Polish Catholics. A spokesman for the Diocese of Berlin, Stefan Foerner, reported that the upward trend in the number of practising Catholics continued, and that the share of the Polish faithful is recorded by parishes along the border, such as Passewalk, Prenzlau, Schwedt and Frankfurt (Oder). S. Foerner added that these numbers concerned only those faithful who are officially registered in a given city, therefore the actual number of the Polish faithful in German churches is much higher; this is the effect of Poles

25 (http://www.tvn24.pl).

26 Bieliński, P. (2017). www.niedziela.pl/artykul/10660/Religijnosc-w-Europie downloaded: December 19, 2017. 
settling in Germany. ${ }^{27}$ According to the clergy, Poles enrich German parishes, and the increase in the number of Polish Catholics in German dioceses is an enrichment for the church. But they also admit that this involves challenges due to different religious traditions. Polish Catholics yearn for their own church songs, as Bishop Wolfgang Ipolt says in an interview for the Catholic press agency, KNA. In addition, there are differences in the form of church sacraments, such as the First Holy Communion or Confirmation, because the rites in both countries slightly differ. The Conference of Catholic Bishops and the Council of the Evangelical Church (EKD) published statistics on 27 Catholic bishoprics and 20 evangelical national churches, which indicate the increase of importance of religion in the lives of the faithful. The data presented for 2016 show that 55 percent of Germany's 82.5 million inhabitants belong to one of both churches. There are also $3.3 \%$ representing the Orthodox Church and other smaller Christian communities. The most numerous group in Germany are Catholics with 23.58 million people (28.5\%) and a small numerical advantage over Protestants who constitute 21.92 million (26.5\%) of the German community. ${ }^{28}$ Being a member of the German Catholic Church is associated not only with participation in the life of the parish, but also with paying the church tax. The amount of tax is determined separately in each federal state and varies, on average, between 6 and $9 \%$ of the income tax. In 2013, the German Catholic Church collected 5.5 billion euros from the believers for the ecclesiastical tax. This is the main source of income for the church in Germany. ${ }^{29}$ In general, there is also a decrease in the number of the faithful, which is caused not only by withdrawal from the Church, but also by demographic processes, including ageing of the German society. Last year, just over 162,000 of the faithful departed from the Catholic Church, and 190,000 from the Evangelical Church. At the same time, 9,048 thousand people joined the Catholic Church.

The authorities of both churches also drew attention to interesting new phenomena in their report. For example, the number of Catholics and Protestants in Bavaria in 2016 fell below 9 million for the first time, while more than 2.7 thousand new Catholics appeared in the archbishopric of Berlin within a year; the increase in the number of believers was also recorded in Hamburg. The smallest bishopric, Goerlitz, counting only 29.2 thousand of the faithful noticed an increase of 482 in the number of Catholics in 2016. This unexpected increase in the number of believers in Berlin and Goerlitz is explained by the inflow of Catholics from Poland. ${ }^{30}$

27 Romaniec, R. (2017). Polacy coraz liczniejsi w niemieckim kościele. In DW, Made for minds, 2015 Permalink http://p.dw.com/p/1H6by downloaded: 16 November 2017.

Ibidem.

29 Ibidem.

$30 \mathrm{kna} /$ afp / Alexandra Jarecka, Społeczeństwo, zaskakujące dane: więcej katolików i ewangelików w Niemczech, Permalink http://p.dw.com/p/2hCPA, July $27^{\text {th }}, 2017$. 
When quoting statistical data, it is worth referring to selected specific situations regarding the current emigration life of Polish-speaking Catholics in Germany. In this respect, interviews were conducted with representatives of two organizations associating Poles in Hamburg, namely "Gazeta Polska" and the Polish Catholic Mission. Analysing individual attitudes in the field of the right to religious practices, there can be noticed discrepancies regarding the issue of manifesting (displaying) national identity through religiosity. There appeared extreme attitudes, especially among Poles associated with "Gazeta Polska," where they saw many difficulties in implementing their own religious rights. In another respect, the right to the freedom of practising Catholicism was presented by Poles associated with the Catholic Mission, presenting a conciliation attitude aimed at reconciling the German' style of thinking about tolerance and human religiosity with the organizational requirements in which Poles operate in Germany. An important element in the functioning of Polish-speaking Catholics in Germany is the statement of the parish priest, representative of the Polish church, that relations with the German church are built on positive contacts and mutual understanding for the good of the Polish community and Polish-speaking Catholics in Germany.

Representatives advocating the increase in the legal guarantee of the freedom of religious practices emphasized the restrictions they faced regarding the rules of organization of religious life. The attention was paid to restrictions on national symbols during Polish masses, restrictions on the display of the Polish flag, images of Saint John Paul II, and posters with Polish prayers. Also the exhibition of works by Udo Lindberg reverberated among those Poles. The staging was interpreted as a presentation of symbols of the Decalogue, shown in several artistic approaches. For many believers, it was offensive and disrespectful for religion, and yet it was presented in the church. In addition, the faithful did not have any influence on its presentation. Such a situation, although controversial, draws attention to the importance of ownership of sacred objects and the right to decide on their use. In Germany, mainly in Hamburg, churches are rented for services for Polish-speaking Catholics, and Polish organizations themselves are not their owners. Hence, decisions about events taking place in them are made by German authorities of the church. In this respect, it is also worth paying attention to the problem of a different understanding of the issue of compromise, pragmatism, and interpretation of human religiosity. In connection to the moderate Catholics' attitudes, there may be a dispute about tolerance, whose boundaries for Germans are more extensive than for Poles. The field of dispute is the issue of religiosity, especially among those who understand the mission and role of the church in the traditional way. Religiosity and rituals are not a private sphere for them, as for Germans, who are guided by pragmatism in the spheres of mutual relations between churches. Pragmatism in everyday contacts begins to dominate the sphere of religious feelings that may be offended when confronted with pragmatics. Slightly 
different aspects are indicated by representatives of moderate views on the space for religious rituals.

In a publication of the Polish Catholic Mission in Germany, we can read that "emigration is an existence in a double culture. There is a peculiar synthesis of what is old: language, culture, tradition, religious-moral values taken out of the family home, with which we identify, with what is new, with the new culture, ideals and goods of the country of settlement. This situation encourages development and opens up new horizons to people. Bicultural education consists in preserving native culture while absorbing the culture of the new environment. Only the bicultural education - knowledge of languages, Christian values, and cultures of both countries will allow for a full upbringing of a European citizen and a Christian deprived of complexes, who finds his or her place in the universal church. "31

An example of promoting the culture, tradition, and religiosity of Polish Catholics is the Parish Saturday School in Hamburg, which was founded at the end of the seventies on the initiative of the then priest, Jan Śliwański, and parents concerned about their children not losing their own roots but learning their native language and Polish culture and history. In the school year 2016/17, over 400 children were taught in this school, both from Polish and national-mixed families. ${ }^{32}$

The interviews conducted in Germany, however, show that not all Polish families fully accept the tolerant multinational German system in which the children of exiled Poles live. For example, the fact that in some kindergartens, the educators are women of Muslim religion, or, for example, young educators with an avant-garde hairstyle and nose rings. The dolls for sexual education with exposed genitals in the kindergarten are also controversial. Although the general assessment of selected families - Polish-speaking Catholics regarding the possibility of practising the Catholic religion or promoting the Polish culture - is positive. Sometimes, however, they get the impression that today, in some cases, the German church focuses more on helping Muslims than Christians.

The subjective anxiety is sometimes raised by displaying catholicity in the form of a cross on a chain around the neck in neighbourhoods where there are more immigrants. One of the examples of mutual positive relations is the annual Christmas meeting with the participation of authorities of the Polish and German church, the Polish diplomatic representation, and the faithful who can take part in such a meeting. Similar meetings are also held on every third Sunday of the month. Polish priests also undertake extensive activities for the benefit of the homeless.

31 Szkoła sobotnia przy Polskiej Misji Katolickiej w Hamburgu - Księga jubileuszowa, Bernardinum, Pelplin 2017, 8.

32 Op. cit., 8, 13. 
Interviews conducted with Polish-speaking Catholics in Hamburg pointed out several problem areas, pointing out various interpretations of the right to religiousness and the scope of manifesting religiosity and national identity. To a large extent, the views differed when respondents viewed religiosity as part of a person's private life, which did not require public manifestation, and when religiosity became a means of displaying Polish identity in exile. 